\title{
PCR DETECTION OF FOUR PERIODONTOPATHOGENS FROM SUBGINGIVAL CLINICAL SAMPLES
}

\author{
Mario Julio Avila-Campos \\ Departamento de Microbiologia, Instituto de Ciências Biomédicas da Universidade de São Paulo, São Paulo, SP, Brasil.
}

Submitted: April 01, 2002; Returned to authors for corrections: October 09, 2002; Approved: December 05, 2002

\begin{abstract}
In this study, A. actinomycetemcomitans, B. forsythus, $P$. gingivalis and $F$. nucleatum were identified from subgingival plaque from 50 periodontal patients and 50 healthy subjects. Subgingival clinical samples were collected with sterilized paper points and transported in VMGA III. From all the diluted clinical samples (1:10), DNA was obtained by boiling, and after centrifugation the supernatant was used as template. Specific primers for each bacterial species were used in PCR. PCR amplification was sensitive to identify these organisms. PCR products from each species showed a single band and can be used to identify periodontal organisms from clinical specimens. PCR detection odds ratio values for A. actinomycetemcomitans and $B$. forsythus were significantly associated with disease showing a higher OR values for B. forsythus (2.97, $95 \%$ CI $1.88-4.70)$. These results suggest a strong association among the studied species and the periodontal lesion.
\end{abstract}

Key words: putative periodontal pathogens, PCR, periodontal disease

\section{INTRODUCTION}

In oral microbiology it is essential to identify and characterize the various microorganisms involved in the different oral infections. Such information will be useful for monitoring the disease progression (6). It is known that periodontal pockets harbor more than 300 different bacterial species (4). The polymerase chain reaction (PCR) is not routinely used in Brazil for the identification of periodontal microorganisms. Several methods for detection of phenotypic or genotypic variation have been used to characterize periodontal pathogens and differentiate them from commensal strains (5).

Organisms such as Actinobacillus actinomycetemcomitans, Fusobacterium nucleatum, Porphyromonas gingivalis, Prevotella intermedia or Eikenella corrodens have been considered to have a role in periodontal disease $(9,11)$. Studies have demonstrated a strong correlation between the presence of putative periodontal organisms and the destruction of periodontal tissues (10).
Molecular methods are currently available for the typing and subtyping of bacterial strains such as A. actinomycetemcomitans and $P$. gingivalis, but they can vary in efficiency and in amount of required labor (7). Techniques such as bacterial culture are used to identify putative anaerobic pathogens from destructive periodontal disease but can be somewhat cumbersome and expensive (12).

Polymerase chain reaction (PCR) has been used for direct identification of periodontal pathogens in subgingival specimens $(3,11)$ and also for elucidating the role of specific bacteria in the periodontal disease because of the ability to accurately detect species in mixed populations. 16S rRNA gene amplification has been used for detection of microorganisms that cannot be cultivated but these methods have given crossreactions with related organisms (11).

The goal of this study was to detect four putative periodontal microorganisms from clinical subgingival and gingival sulcus samples by $16 \mathrm{~S}$ rRNA gene-based detection PCR methods.

\footnotetext{
* Corresponding author. Mailing address: Departamento de Microbiologia, Instituto de Ciências Biomédicas II, Universidade de São Paulo. Av. Prof. Lineu Prestes, 1374, Cidade Universitária. 05508-000, São Paulo, SP, Brasil. Telephone: (+5511) 3091-7344. Fax: (+5511) 3091-7354. E-mail: mariojac@usp.br
} 


\section{MATERIALS AND METHODS}

\section{Patients and clinical samples}

Fifty periodontal patients were selected from the School of Dentistry, at the University of São Paulo (São Paulo, SP, Brazil). All the patients showed clinical and radiographic evidence of alveolar loss confined to the molar and incisor teeth and periodontal pockets depth equal or exceeding $5 \mathrm{~mm}$. Fifty healthy subjects without clinical signs of periodontal disease were also selected. Characteristics of both of the studied groups are showed in Table 1. None of patients or controls had used antibiotics during at least three months prior of the sample collection. Briefly, subgingival dental plaque was removed from the mesial surface of two affected teeth by means of sterile cotton rolls. Subgingival bacterial samples were obtained by three fine sterile paper points (Dentsply Ind. and Co. Ltd., RJ, Brazil) inserted to the depth of each study site and left in place for $60 \mathrm{~s}$ (2). The paper points were transported in VMGA III medium (8).

Table 1. Characteristics of periodontal patients and healthy subjects analyzed

\begin{tabular}{|c|c|c|c|c|}
\hline & \multicolumn{2}{|c|}{$\begin{array}{l}\text { Periodontal patients } \\
\qquad(n=50)\end{array}$} & \multicolumn{2}{|c|}{$\begin{array}{l}\text { Healthy subject } \\
\quad(n=50)\end{array}$} \\
\hline & Average (\%) & $\overline{\text { Range }}$ & Average (\%) & Range \\
\hline Age (years) & 45.5 & $18-65$ & 32.3 & $18-51$ \\
\hline Race: & & & & \\
\hline White & 40 & - & 40 & - \\
\hline Black & 9 & - & 10 & - \\
\hline Oriental & 1 & - & - & - \\
\hline Tooth (No.) & 25.1 & $11-47$ & 13 & - \\
\hline $\begin{array}{l}\text { Periodontal } \\
\text { pocket }(\mathrm{mm})\end{array}$ & 8.4 & $6-13$ & - & - \\
\hline
\end{tabular}

\section{DNA extraction and analysis}

From each clinical sample collected in VMGA III, $500 \mu \mathrm{l}$ of sample was mixed with $500 \mu$ lof sterile Milli-Q water and washed twice at $12,000 \mathrm{x}$, for 10 minutes. The pellet was resuspended in $500 \mu \mathrm{l}$ of Milli-Q water and boiled for 10 minutes. After centrifugation $(14,000 \mathrm{x} g, 10$ minutes) the supernatant was saved and transferred to a new tube and used as template.

\section{PCR detection}

Fifty clinical samples obtained from patients with adult periodontitis and 50 samples from healthy subjects were included in the PCR analysis. Primers (Table 2) were designed in accordance with Ashimoto et al. (1) and Avila-Campos et al. (3), and were synthesized in the Biotechnology Core Facility Branch, Centers for Disease Control and Prevention (CDC, Atlanta, GA, USA). PCR amplification was performed in volumes of $25 \mu$ l containing $1 \mathrm{X}$ PCR/ $\mathrm{Mg}^{++}$buffer (Boehring Mannheim, Indianopolis, IN, USA), $0.2 \mathrm{mM}$ each of dNTP (Pharmacia Biotech, Piscataway, NJ, USA), 0.5 U Taq DNA polymerase (Boehringer Mannheim), $0.4 \mu \mathrm{M}$ of each primer pair and $10 \mathrm{ng}$ of template. Amplification was performed in a DNA Thermal Cycler (Perkin Elmer, GeneAmp PCR System 2400 , Norwalk, CT, USA) programmed for $94^{\circ} \mathrm{C}$ (5 min), followed by 30 cycles with adequate annealing temperature for each primer pair (Table 2$)$, then $72^{\circ} \mathrm{C}(5 \mathrm{~min})$ to allow the completion of DNA extension. A negative control without template DNA was included in each PCR run. Amplification products were compared by electrophoresis in $1 \%$ agarose gel in $1 \mathrm{X}$ TBE (1 M Tris, 0.9 M boric acid, 0.01 M EDTA, pH 8.4) buffer (Gibco BRL, Life Technologies, Ltd., Bethesda, MD, USA), stained with ethidium bromide $(0.5 \mu \mathrm{g} / \mathrm{ml})$, and photographed on a UV light transilluminator (Kodak Digital Science System 120). Molecular mass standard 1-Kb ladder (Gibco BRL) was included.

Table 2. Nomenclature, composition and annealing temperature of the species-specific primer pairs for PCR.

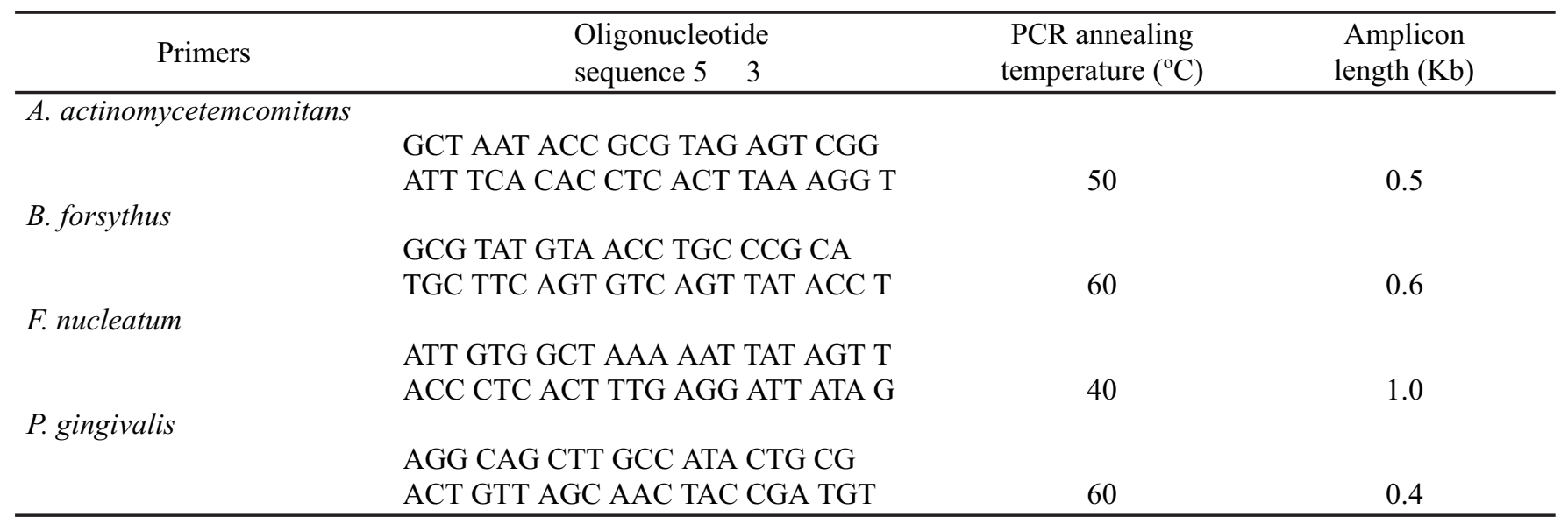

Kb: kilobases. 
Table 3. Percentage of positive samples and odds ratios (confidence interval-CI 95\%) for each tested organism isolated from healthy and periodontal subjects.

\begin{tabular}{lcccc}
\hline & \multicolumn{4}{c}{ PCR detection } \\
\cline { 2 - 5 } \multicolumn{1}{c}{ Microorganism } & Healthy subjects & Periodontal patients & OR (95\% CI) & $P$ values \\
\hline A. actinomycetemcomitans & 70 & 90 & $1.71(1.20-2.44)$ & 0.024 \\
B. forsythus & 30 & 82 & $2.97(1.88-4.70)$ & 0.00047 \\
P. gingivalis & 66 & 78 & $1.32(0.90-1.96)$ & 0.260 \\
F. nucleatum & 92 & 96 & $1.36(0.75-2.49)$ & 0.67 \\
\hline
\end{tabular}

\section{Statistical Analysis}

All statistical analysis was performed using an Epi-info ${ }^{\circledR} 6.04$ sofware (CDC/WHO). Standard methods to calculate descriptive statistics were used. The association between microbial detection by culture and PCR and periodontal disease was tested using a chi-square test ( $p$ values are two-sided and $\alpha=0.05$ ) and the odds ratios were calculated (OR, $95 \%$ confidence interval).

\section{RESULTS}

\section{Bacterial Prevalence detected by PCR}

Primer pairs were used for identification of four different putative periodontopathogens. Amplification products using control strain DNA were compared and all primer pairs produced amplicons of the predicted sizes. In Table 3, the frequencies of bacterial detection in 50 healthy subjects and 50 periodontal patients are reported. Bacterial detection in the healthy and periodontitis subjects was $70 \%$ and $90 \%$ for $A$. actinomycetemcomitans, $30 \%$ and $82 \%$ for B. forsythus, $66 \%$ and $78 \%$ for $P$. gingivalis and, $92 \%$ and $96 \%$ for $F$. nucleatum. In addition, the odds ratios (OR, 95\% confidence interval-CI) for periodontal patients compared to control are also given in Table 3. Detected A. actinomycetemcomitans and B. forsythus by PCR were significantly associated with periodontal disease, and $B$. forsythus showed the highest OR $(2.97,95 \%$ CI $1.88-4.70)$.

\section{DISCUSSION}

PCR analysis was used successfully to identify different periodontopathogens associated with human periodontitis such as A. actinomycetemcomitans, $B$. forsythus, $P$. gingivalis or $F$. nucleatum. On the other hand, further studies should be done to demonstrate the value of $16 \mathrm{~S}$ PCR for species-specific detection of A. actinomycetemcomitans in clinical samples (in VMGA III medium) from patients with periodontitis. Also, the obvious risk for dilution and loosing sensitivity by this procedure was not observed.

The DNA amplifications from subgingival plaque suggest that hemoglobin or other compounds in subgingival specimens do not significantly inhibit the PCR reaction (3). The presence of dead bacteria within the sample may have increased the detection using the PCR method, but it is unlikely that dead cells remain in the subgingival biofilm for very long, being degraded and disposed of by the other bacteria.

The prevalence of $A$. actinomycetemcomitans and $B$. forsythus was significantly higher by PCR detection $(p \leq 0.05)$. $F$. nucleatum was the most commonly detected species in both the healthy and periodontal subjects by PCR detection. Also, A. actinomycetemcomitans and $P$. gingivalis were prevalent in both of studied groups, and it may suggest that these three organisms (including F. nucleatum) may be part of the oral indigenous microbiota. Our data also revealed a lower prevalence of $B$. forsythus in healthy subjects suggesting that these pathogens may be increased in periodontal infectious processes.

Higher odds ratios observed for these detected periodontal organisms can suggest a symbiotic relationship in periodontal pockets producing a destructive disease without interacting with each other. However, a suitable therapeutic to obtain a bacterial elimination may be of great clinical benefits (1). The use of the specific primers represent an appropriate tool to identify or detect periodontal pathogens from mixed bacterial populations.

\section{ACKNOWLEDGEMENTS}

The authors thank Dr. Leonard W. Mayer for his collaboration and critical review, and Dr. Gustavo VelásquezMeléndez for the statistical analysis. This study was supported by grant from Fundação de Amparo à Pesquisa do Estado de São Paulo (FAPESP), SP, Proc. No. 98/15572-8, and Conselho Nacional de Desenvolvimento Científico e Tecnológico (CNPq) Proc. No. 301610/92-4, Brasilia, DF, Brazil.

\section{RESUMO}

\section{Detecção por PCR de quatro periodontopatógenos de pacientes com doença periodontal e de indivíduos sadios}

Em nosso estudo quatro periodontopatógenos foram isolados e identificados de placas subgengivais de 50 pacientes 
com doença periodontal e de 50 indivíduos sadios. As placas subgengivais foram coletadas com pontas de papel e transportadas em VMGA III. Foram realizadas diluições seriadas das amostras clínicas (1:10), e os DNA foram obtidos por fervura. Iniciadores específicos para cada bactéria foram usados no PCR. As amplificações mostraram-se sensíveis na identificação de $A$. actinomycetemcomitans, $B$. forsythus, $P$. gingivalis e $F$. nucleatum. As reações de PCR produziram bandas específicas para cada espécie e podem ser usadas na identificação desses organismos periodontais diretamente das amostras clínicas. Os valores de odds ratio para a detecção de $A$. actinomycetemcomitans e $B$. forsythus foram significativamente associados com a doença periodontal mostrando altos valores de OR para B. forsythus $(2,97,95 \%$ CI 1,88 - 4,70). Esses resultados sugerem uma forte associação entre os organismos estudados e a lesão periodontal.

Palavras-chave: patógenos periodontais, PCR, doença periodontal.

\section{REFERENCES}

1. Ashimoto, A.; Chen, C.; Bakker, I.; Slots, J. Polymerase chain reaction detection of 8 putative periodontal pathogens in subgingival plaque of gingivitis and advanced periodontitis lesions. Oral Microbiol. Immunol., 11: 266-273, 1996.

2. Avila-Campos, M.J.; Farias, L.M.; Carvalho, M.A.R.; Damasceno, C.A.V.; Cisalpino, E.O.; Costa, J.E. Aspectos ecológicos de Actinobacillus actinomycetemcomitans: aislamiento y caracterización de cepas. Rev. Lat-amer. Microbiol., 30: 301-305, 1988.
3. Avila-Campos, M.J.; Sacchi, C.T.; Whitney, A.M.; Steigerwalt, A.G.; Mayer, L.W. Arbitrary primed-polymerase chain reaction for identification and epidemiologic subtyping of oral isolates of Fusobacterium nucleatum. J. Periodontol., 70: 1202-1208, 1999.

4. Bolstad, A.I.; Jensen, H.B. Polymerase chain reaction-amplified nonradioactive probes for identification of Fusobacterium nucleatum. J. Clin. Microbiol., 31: 528-532, 1993.

5. Eisenstein, B.I. New molecular techniques for microbial epidemiology and the diagnosis of infectious diseases. J. Infect. Dis., 161: 595602, 1990.

6. Furcht, C.; Eschrich, K.; Merte, K. Detection of Eikenella corrodens and Actinobacillus actinomycetemcomitans by use of the polymerase chain reaction (PCR) in vitro and in subgingival plaque. J. Clin. Periodontol., 23: 891-897, 1996.

7. Ménard, C.; Brousseau, R.; Mouton, C. Application of polymerase chain reaction with arbitrary primer (AP-PCR) to strain identification of Porphyromonas (Bacteroides) gingivalis. FEMS Microbiol. Lett., 95: 163-168, 1992.

8. Möller, A.J.R. Microbiological examination of root canals and periapical tisues of human teeth. Odontologisk Tidskrift., 74: 1-380, 1966.

9. Newman, M.G.; Socransky, S.S.; Savitt, E.; Propas, D.; Crawford, A.A. Studies of the microbiology of periodontitis. J. Periodontol., 47: 373-379, 1976.

10. Newman, M.G.; Socransky, S.S. Predominant cultivable microbiota in periodontitis. J. Periodontol. Res., 12: 120-128, 1977.

11. Slots, J.; Ashimoto, A.; Flynn, M.J.; Li, G.; Chen, C. Detection of putative pathogens in subgingival specimens by $16 \mathrm{~S}$ ribosomal DNA amplification with the polymerase chain reaction. Clin. Infect. Dis., 20: 304-307, 1995.

12. Watanabe, K.; Frommel, T. O. Porphyromonas gingivalis, Actinobacillus actinomycetemcomitans and Treponema denticola detection in oral plaque samples using the polymerase chain reaction. J. Clin. Periodontol., 23: 212-219, 1996. 